Research Article

\title{
Comparative karyotype analysis of populations in the Alstroemeria presliana Herbert (Alstroemeriaceae) complex in Chile
}

\author{
Carlos Baeza ${ }^{1}$, Víctor L. Finot ${ }^{2}$ and Eduardo Ruiz ${ }^{1}$ \\ ${ }^{1}$ Departamento de Botánica, Facultad de Ciencias Naturales y Oceanográficas, \\ Universidad de Concepción, Concepción, Chile. \\ ${ }^{2}$ Departamento de Producción Animal, Facultad de Agronomía, Universidad de Concepción, Chillán.
}

\begin{abstract}
Alstroemeria L., one of the most diverse genera of the Chilean flora and of high floricultural value, is represented by 35 species, most of them distributed between $28-38^{\circ} S$ in the Mediterranean zone of Central Chile. There are 24 complex-forming taxa, of which 18 have conservation problems (8 are considered "endangered" and 10 as "vulnerable"). One of these complexes is Alstroemeria presliana Herb. with two subspecies: subsp. presliana and subsp. australis Bayer. Alstroemeria presliana grows in Chile and Argentina: subsp. presliana is distributed from Reserva Nacional Siete Tazas ( $35^{\circ} 27^{\prime}$ S, Region of Maule) to Antuco, (37 $25^{\prime}$ S, Region of Bío-Bío), and is also found in Neuquén, Argentina; subsp. australis is endemic to the Cordillera of Nahuelbuta. A comparative karyotype study was carried out among six populations of $A$. presliana subsp. presliana and five populations of $A$. presliana subsp. australis. The eleven populations presented an asymmetric karyotype, with $2 n=2 x=16$ chromosomes but with different karyotype formulae. A. presliana subsp. presliana shows the haploid formula $2 \mathrm{~m}+2 \mathrm{~m}$-sat $+1 \mathrm{sm}$-sat $+1 \mathrm{st}-\mathrm{sat}+1 \mathrm{t}+$ $1 \mathrm{t}$-sat, and $A$. presliana subsp. australis presents a formula $1 \mathrm{~m}+2 \mathrm{~m}$-sat $+1 \mathrm{sm}+2 \mathrm{t}+2 \mathrm{t}$-sat chromosomes. The architecture of the karyotype between the subspecies is very different. The scatter plot among $C V_{C L} v s$. $M_{C A}$ shows different groupings between populations of the two subspecies. According to the results obtained it is possible to consider raising Alstroemeria presliana subsp. australis at species level.
\end{abstract}

Keywords: Alstroemeria, asymmetry, Chile, karyotype, species complex.

Received: September 23, 2014; Accepted: November 18, 2014.

\section{Introduction}

Chile has important endemic biodiversity, especially in its vascular flora. Forty-six percent of the Chilean vascular taxa are endemic (Marticorena, 1990), and many of them present conservation problems (Muñoz and Moreira, 2003). For this reason, Chile has been included among the world biodiversity hotspots (Arroyo et al., 1999; Myers et al., 2000; Mittermeier et al., 2004). The large environmental diversity of Chile (Cowling et al., 1996; Arroyo et al., 2008) and consequently the different selective pressures, would likely stimulate active micro-evolutionary processes that would result in high floristic diversity, as well as high levels of endemism. Several parameters contribute to this ecological heterogeneity: the wide latitudinal and altitudinal gradient, the insular character, and the historical isolation from the rest of the vegetation of the continent (Villagrán and Hinojoza, 1997; Armesto et al., 1998; Lazo et al., 2008). This would also have implications for the occur-

Send correspondence to Carlos Baeza. Departamento de Botánica, Facultad de Ciencias Naturales y Oceanográficas, Universidad de Concepción, Casilla 160-C, Concepción, Chile. E-mail: cbaeza@udec.cl. rence of subspecific and/or varietal complexes that are very difficult to resolve taxonomically.

A zone of special interest in the Chilean hotspot is the Mediterranean zone, which extends between $23^{\circ}$ and $38^{\circ} \mathrm{S}$ (Amigo and Ramírez, 1998), and which harbors a great diversity of environments (Di Castri, 1981). In this region, several plant genera exhibit their maximum floristic diversification and high levels of endemism, such as Adesmia (Burkart, 1967), Alstroemeria (Bayer, 1987; Muñoz and Moreira, 2003; Moreira, 2011), Calceolaria (Ehrhart, 2000), and Escallonia (Sleumer, 1968). As in most zones with Mediterranean climate of the world, in central Chile there is a large number of species with restricted distribution and with high probability of extinction (Cowling et al., 1996). Moreover, this is also the zone of the country that concentrates the highest human population, accompanied by intense anthropic intervention due to agriculture and forest activities, as well as urbanization (Vergara et al., 2006).

Economic utilization of the floristic diversity within Chile has led to a vibrant floriculture market that has undergone strong growth in the last decade. One of the families with a large number of endemic species in Chile is Alstroemeriaceae, which contains several species with high po- 
tential for the floriculture market (Baeza et al., 2011 a,b). Given the beauty of the flowers, Chilean species of Alstroemeria have achieved worldwide recognition as desirable ornamental and cut plants (Buitendijk and Ramanna, 1996; Buitendijk et al., 1997), and many species have attained a high commercial value (Stephens et al., 1993). Countries such as Holland, England, Japan and the United States have created breeding and propagation programs for commercial species (Miyake et al., 1989; Jeu et al., 1992), and hybrids originated from Chilean species by means of genetic engineering have come back to their place of origin as import products (Muñoz and Moreira, 2003). A good example of this is provided by species such as $A$. aurea R.Graham, A. ligtu L. and A. pelegrina L., among others. Many cultivars have originated from site-specific breeding that consists of haploid, triploid and tetraploid forms, with increased beauty and duration of the flowers (Kuipers et al., 1997). Morphologically, Chilean species of Alstroemeria have been studied in detail, first by Bayer (1987) who described, illustrated, provided distributions, and included photographs of 42 taxa in 31 species. Later, Muñoz (2000, 2003) described 3 new species and one variety, and finally, Muñoz and Moreira (2003) published a beautifully illustrated book on the biodiversity, distribution, and conservation of this genus in Chile.

Alstroemeria is one of the most diverse genera of the Chilean flora, and it is represented by 35 species, most of them distributed between $28^{\circ} \mathrm{S}$ and $39^{\circ} \mathrm{S}$ (Muñoz and Moreira, 2003) in the Mediterranean zone (Amigo and Ramírez, 1998). Eleven species of this genus contain complexes of two to four intraspecific taxonomic entities (subspecies and varieties). Representatives in each of these complexes grow in the Chilean Mediterranean zone and some of them are endemic to this region, with a very restricted distribution (Bayer, 1987; Muñoz and Moreira, 2003). Alstroemeria presliana Herb. includes two subspecies: subsp. presliana (Figure 1A), and subsp. australis Bayer (Figure 1B). They grow in a restricted fashion in Chile from the cordillera of Curicó $\left(35^{\circ} 27^{\prime} \mathrm{S}\right)$ to the cordillera of Antuco ( $\left.37^{\circ} 25^{\prime} \mathrm{S}\right)$, and from 1500 to $2000 \mathrm{~m}$ elevation; they also occur in Neuquén Province of Argentina. Alstroemeria presliana subsp. australis is endemic to Chile, occupying a narrow geographic distribution, from Curanilahue ( $\left.37^{\circ} 23^{\prime} \mathrm{S}\right)$ south to the river Cautin (38 $\left.29^{\prime} \mathrm{S}\right)$, and from 200-1500 m elevation (Muñoz and Moreira, 2003). Baeza et al. (2008) completed a comparative karyotype study of one population of $A$. presliana subsp. presliana and one population of subsp. australis, which revealed two different karyotype formulae. It would therefore, be very interesting, to analyze more populations of both subspecies to determine the stability of karyotype structure within each. Both subspecies have attractive pink flowers that can be differentiated primarily by the size and color of their tepals, in addition to geographic distribution. This species represents, therefore, a high potential for development as an or- namental plant that has so far not been successfully developed.

The study of karyotype is a valuable tool for comparison of populations either within the same or among different species (Schrader et al., 2000, 2003; Matsumoto et al., 2000). The study of karyotype variation is important not only as a tool for evidence of sources of genetic variability, but also because it represents an important micro-morphological feature for understanding evolution within species. Detailed analysis of the chromosomes of related taxa can provide valuable information concerning their evolution and taxonomy (Dimitrova and Greilhuber, 2000). The objective of this research, therefore, has been to cytogenetically characterize and compare the two subspecies of the $A$. presliana complex throughout its entire distribution, and to clarify their taxonomic status.

\section{Materials and Methods}

\section{Plant material}

The material of Alstroemeria presliana analyzed came from 11 populations, six from subsp. presliana and five from subsp. australis (Figure 1C). Vouchers were deposited in the herbarium of the Universidad de Concepción (CONC). Sources of material were as follows:

Alstroemeria presliana subsp. presliana: Región del Bío-Bío, Provincia de Biobío, Comuna de Yungay, Hacienda Rucamanqui, Sendero Cerro Manque, $1200 \mathrm{~m}, 37^{\circ} 11^{\prime}$ S, $71^{\circ} 43^{\prime}$ W, C. Baeza \& J. Espejo 4362 (CONC). Región del Bío-Bío, Provincia de Nuble, Comuna de Pinto, entrada a Fundo Los Pellines, $727 \mathrm{~m}\left(36^{\circ} 49^{\prime} \mathrm{S}, 71^{\circ} 36^{\prime} \mathrm{W}\right), \mathrm{C}$. Baeza 4364 (CONC). Región del Bío-Bío, Provincia de Ñuble, Comuna de Pinto, Fundo Los Pretiles, sector Las Piedras, 1300 m (36 53' S, 71³6' W), C. Baeza 4365 (CONC). Región del Bío-Bío, Provincia de Nuuble, Termas de Chillán, ca. 500 m más arriba del Hotel Termas de Chillán, a 50 m de La Virgen, 1608 m (36 54' S-71⒉ $4^{\prime}$ 'W), C. Baeza 4192 (CONC). Región del Bío-Bío, Provincia de Nuble, Comuna de Pinto, Frente a la entrada a la Cueva de Los Pincheira 1000 m (36 $53^{\prime}$ S- 71 $1^{\circ} 33^{\prime}$ W), C. Baeza 4372 (CONC). VII Región, Provincia de Curicó, Comuna de Molina. Parque Nacional Radal 7 Tazas, sendero Malacara, C. Baeza 4373.

Alstroemeria presliana subsp. australis. Region of the Araucanía, Provincia de Malleco, camino al Parque Nacional Nahuelbuta, a $500 \mathrm{~m}$ de Vegas Blancas, bosquecito de Roble, 795 m (3749’ S-7254’ W), C. Baeza 4369 (CONC). IX Región, Provincia de Malleco, Parque Nacional Nahuelbuta, Piedra del Águila, 1350 m (3749' S$73^{\circ} 08^{\prime}$ W), C. Baeza 4250 C. IX Región, Provincia de Malleco, camino al Parque Nacional Nahuelbuta, a $50 \mathrm{~m}$ de la entrada al Parque, en un bosque de Roble, $1250 \mathrm{~m}$ (3749’ S-7257’ W), C. Baeza 4370 (CONC). IX Región, Provincia de Malleco, camino desde el Puente El manzano a Angol, 690 m (37 $47^{\prime}$ S- $72^{\circ} 50^{\prime}$ W), C. Baeza 4371 

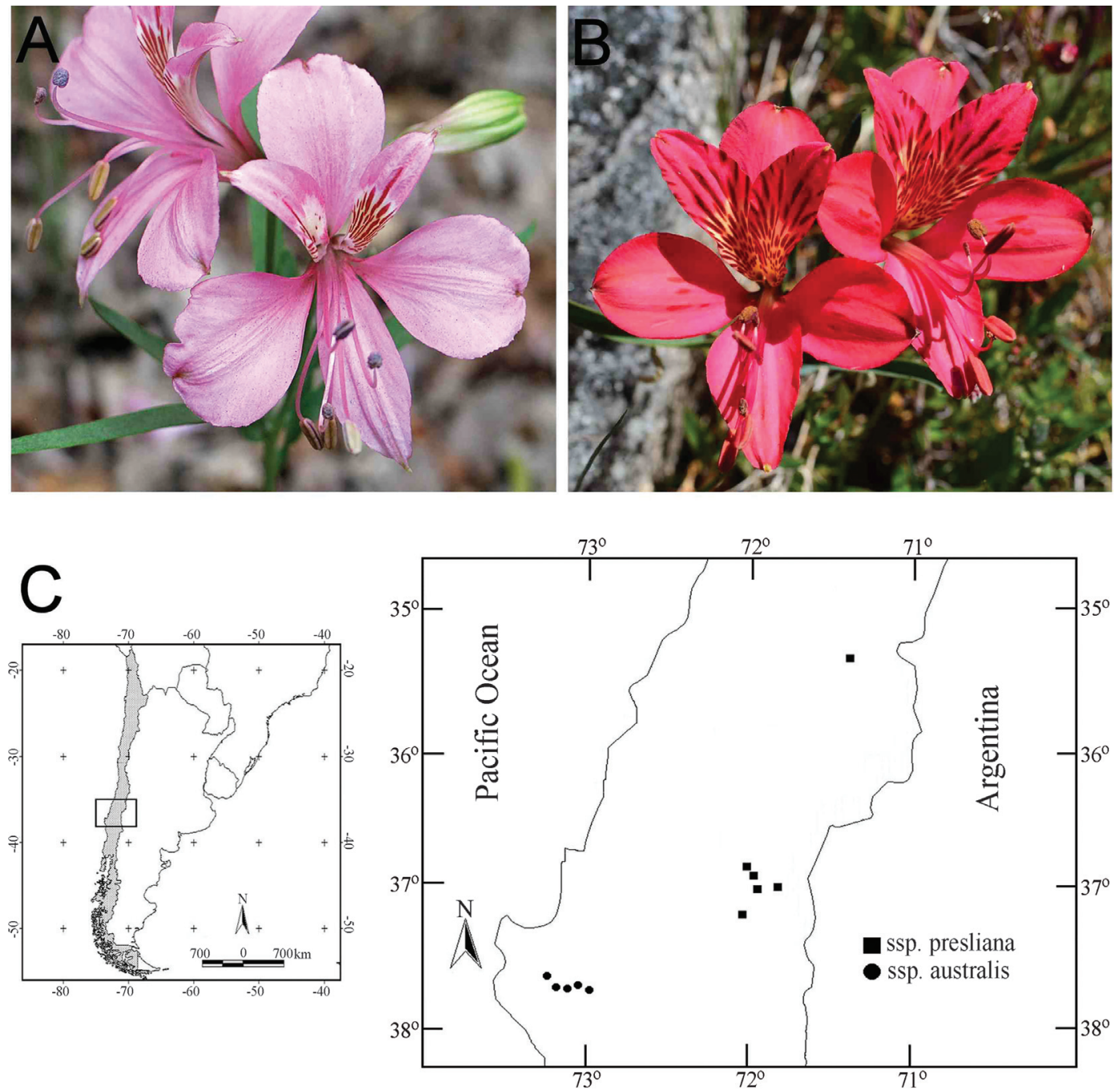

Figure 1 - Photographic representation and geographic distribution of Alstroemeria presliana. (A) Photography of Alstroemeria presliana subsp. presliana; (B) Photography of Alstroemeria presliana subsp. australis; (C) Geographic distribution of the 11 analyzed populations of Alstroemeria presliana.

(CONC). IX Región, Provincia de Malleco, Trongol, Piedra del Queso, Caramávida, 1222 m (37³9’ S- 7306’ W), G. Fuentes s.n.

\section{Methodology for the study of karyotypes}

Roots (1-2 cm long) obtained from material cultured in a greenhouse were cut and pre-treated with a solution of hydroxyquinoline $(2 \mathrm{mM})$ for $24 \mathrm{~h}$ at $4{ }^{\circ} \mathrm{C}$. Subsequently, they were fixed in a mixture of ethanol/acetic acid $(3: 1)$ for $24 \mathrm{~h}$. Root tips were then squashed in an acid hydrolysis of $\mathrm{HCl} 0.5 \mathrm{~N}$ for $18 \mathrm{~min}$ at $45^{\circ} \mathrm{C}$, followed by washing and staining with $1 \%$ orcein. Metaphase plates were photographed with a Zeiss Axioskop microscope equipped with a digital camera, and the pictures were analyzed with Paint Shop Pro Photo X2. Chromosomes were measured with the assistance of the software MicroMeasure 3.3 (Reeves, 2001) and classified according to arm ratios (long arm/short arm; modified from Levan et al., 1964), catego- rized by position of the centromere: 1.0-1.7 (metacentric, $\mathrm{m}$ ); 1.7-3.0 (submetacentric, sm); 3.0-7.0 (subtelocentric,

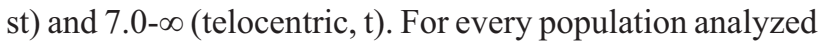
(10 metaphase plates), the intrachromosomal asymmetry index $\mathrm{M}_{\mathrm{CA}}$ and the interchromosomal asymmetry index $\mathrm{CV}_{\mathrm{CL}}$ was calculated (Peruzzi and Eroglu, 2013).

\section{Results and Discussion}

The eleven analyzed populations of Alstroemeria presliana present $2 n=2 x=16$ chromosomes. A. presliana subsp. presliana has a haploid formula of $2 \mathrm{~m}+2 \mathrm{~m}$-sat + $1 \mathrm{sm}$-sat $+1 \mathrm{st}-\mathrm{sat}+1 \mathrm{t}+1 \mathrm{t}$-sat, i.e., two pairs of metacentric chromosomes, two metacentric chromosomes with satellite, one submetacentric pair with satellite, one subtelocentric pair with satellite, one telocentric pair, and one telocentric pair with satellite. A. presliana subsp. australis has a haploid formula of $1 \mathrm{~m}+2 \mathrm{~m}$-sat $+1 \mathrm{sm}+2 \mathrm{t}+2 \mathrm{t}$-sat, i.e., one pair of metacentric chromosomes, two metacentric 
pairs with satellite, one submetacentric pair, two telocentric pairs, and two telocentric pairs with satellite. The karyotypes of the two subspecies are shown in Figure 2. Values of the karyotype asymmetry index $\mathrm{CV}_{\mathrm{CL}}$ and $\mathrm{M}_{\mathrm{CA}}$ are summarized in Table 1. Figure 3 represents the dispersion of the data in relation to the $\mathrm{CV}_{\mathrm{CL}}$ and $\mathrm{M}_{\mathrm{CA}}$ indices of Peruzzi and Eroglu (2013). The analyses are based on ten metaphases from each population.

Preliminary studies (Baeza et al., 2008) in the Alstroemeria presliana complex revealed the presence of karyotype variability between subspecies presliana and australis. This variability was observed both in the karyotype morphology, as well as in the presence or absence of secondary constrictions and satellites. This study, however, included examination of only one population from each subspecies. The present study of five populations of subsp. australis and six of subsp. presliana have corroborated these differences. In a detailed comparison of the karyotypes (Figure 2), one observes large differences in asymmetry as well as architecture. Subsp. presliana has three pairs of large metacentric chromosomes, the second pair with satellites in the terminal zone of the short arm, whereas subsp. australis has only two large pairs of metacentric chromosomes. This situation is similar to that reported by Baeza et al. (2010) for the A. hookeri complex, where a cytological comparison was made between populations of subsp. hookeri of the coast of Region VIII of Chile and of the Pangal de Laja (zone of the intermediate depression). Based on this former study, plus that of Baeza and Ruiz (2011), a new subspecies was described within the complex, $A$. hookeri subsp. sansebastiana, endemic to Region VIII. Coincidentally, the populations of A. hookeri, as those of A. presliana confined to the Nahuelbuta cordillera present karyotypes that are more symmetrical and with large metacentric chromosomes. In both subspecies of $A$. presliana, chromosomes 1 and 2 are identical, the third pair is distinct, chromosome 4 is telocentric in both subspecies,

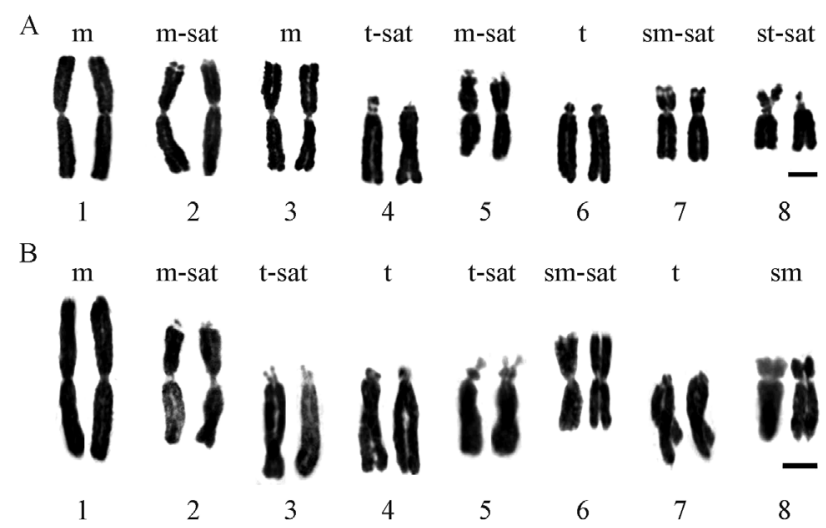

Figure 2 - Karyotypes of the Alstroemeria presliana populations (A) A. presliana subsp. presliana (populations 4192, 4362, 4364, 4365, 4372, and 4373); (B) A. presliana subsp. australis (populations $4250 \mathrm{C}, 4369$, 4370, 4371, and G. Fuentes s.n.). Scale bar $=5 \mu \mathrm{m}$.

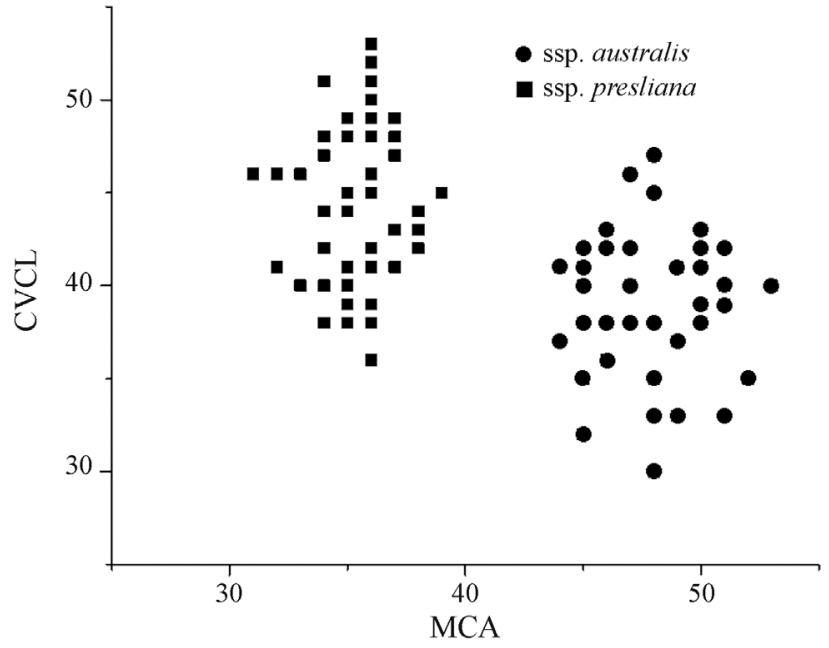

Figure 3 - Scatter plot among populations of Alstroemeria presliana subspecies using values of $\mathrm{M}_{\mathrm{CA}}$ vs. $\mathrm{CV}_{\mathrm{CL}}$.

although subsp. presliana has a satellite on the short arm. The rest of the chromosomes are dissimilar in karyotype morphology between the two subspecies, which emphasizes their enormous overall difference in architecture. This is further corroborated if one compares the karyotype asymmetry index used (Table 1). Figure 3 shows a diagram of the dispersion of the $\mathrm{M}_{\mathrm{CA}} v s$. $\mathrm{CV}_{\mathrm{CL}}$ values of Peruzzi and Eroglu (2013) based on analyses of all individuals and populations. Two clusters of points can be seen, the squares representing populations of subsp. presliana and the circles subsp. australis. The major variation is observed in the intrachromosomal index $\left(\mathrm{M}_{\mathrm{CA}}\right)$, as much within each subspecies as between them. Variation is less with the interchromosomal index $\left(\mathrm{CV}_{\mathrm{CL}}\right)$ in the populations of subsp. presliana and somewhat greater in subsp. australis, although it is very different between the subspecies. Defini-

Table 1 - Karyotype features of the subspecies of Alstroemeria presliana. $\mathrm{CV}_{\mathrm{CL}}=$ Coefficient of variation of chromosome length; $\mathrm{M}_{\mathrm{CA}}=$ Mean centromeric asymmetry index according to Peruzzi and Eroglu (2013); $\mathrm{SD}=$ Standard deviation

\begin{tabular}{lll}
\hline Populations & $\mathrm{CV}_{\mathrm{CL}} \pm \mathrm{SD}$ & $\mathrm{M}_{\mathrm{CA}} \pm \mathrm{SD}$ \\
\hline A. presliana subsp. presliana (4192) & $39.8 \pm 2.70$ & $36.0 \pm 0.01$ \\
A. presliana subsp. presliana (4362) & $44.8 \pm 4.96$ & $34.4 \pm 0.01$ \\
A. presliana subsp. presliana (4364) & $45.9 \pm 3.48$ & $34.9 \pm 0.03$ \\
A. presliana subsp. presliana (4365) & $42.6 \pm 3.92$ & $36.2 \pm 0.01$ \\
A. presliana subsp. presliana (4372) & $46.4 \pm 4.25$ & $35.3 \pm 0.02$ \\
A. presliana subsp. presliana (4373) & $44.9 \pm 3.97$ & $35.7 \pm 0.02$ \\
A. presliana subsp. australis (4250 C) & $36.3 \pm 4.85$ & $48.7 \pm 0.01$ \\
A. presliana subsp. australis (4369) & $42.2 \pm 6.12$ & $46.5 \pm 0.02$ \\
A. presliana subsp. australis (4370) & $39.0 \pm 4.47$ & $48.8 \pm 0.02$ \\
A. presliana subsp. australis (4371) & $38.4 \pm 3.45$ & $49.4 \pm 0.02$ \\
A. presliana subsp. australis (Fuentes) & $38.2 \pm 4.39$ & $46.4 \pm 0.02$ \\
\hline
\end{tabular}


tively, this diagram yields the conclusion that there exists a clear difference in dispersion between the populations of the two subspecies.

Bayer (1987) separated subspecies presliana and australis based on color of the tepals, length of the external tepals, color and ornamentation of the internal tepals, and anther color. Muñoz and Moreira (2003) considered that the larger, intensely pink flowers are diagnostic features that allow separation of subsp. australis from subsp. presliana. The cytogenetic results presented here, in combination with a morphometric analysis of tepal color in CIELAB space (unpublished data), provide evidence to suggest species rank for the two taxa. These studies also demonstrate that the subsp. presliana grows exclusively in the cordillera of Los Andes and that the subsp. australis is endemic to the cordillera of Nahuelbuta. Taken together, we conclude that $A$. presliana subsp. australis should be considered as distinct species.

\section{Acknowledgments}

This work was supported by Fondecyt grant $\mathrm{N}^{\circ}$ 1130349. We thank Tod Stuessy (Ohio State University, USA) for improving the English and Gabriele Kottirsch and Janina Baeza for technical assistance in the field. We are grateful to the Corporación Nacional Forestal of Chile (CONAF) for allowing collection of samples in the Nahuelbuta and Radal 7 Tazas National Park. Finally, the authors acknowledge the suggestions of two anonymous reviewers of this article.

\section{References}

Amigo J and Ramírez C (1998) A bioclimatic classification of Chile: Woodland communities in the temperate zone. Plant Ecol 136:9-26.

Armesto J, Rozzi R, Smith-Ramírez C and Arroyo M (1998) Conservation targets in South American temperate forests. Science 282:1271-1272.

Arroyo M, Rozzi R, Simonetti J, Marquet P and Salaberry M (1999) Central Chile. In: Mittermeier R Myers N Robles Gil P and Goettsch Mittermeier C (eds) Hotspots: Earth's Biologically Richest and Most Endangered Terrestrial Ecorregions. CEMEX, México, pp 161-171.

Arroyo M, Marquet P, Marticorena C, Simoneti J, Cavieres L, Squeo F, Roíz R and Massardo F (2008) El hotspot chileno, prioridad mundial para la conservación. In: Rovira J, Ugalde J and Stutzin M (eds) Biodiversidad de Chile, Patrimonio y Desafíos, Ocho Libros Editores, Santiago de Chile, pp. 9093.

Baeza C and Ruiz E (2011) Alstroemeria hookeri Lodd. subsp. sansebastiana C.M. Baeza \& E. Ruiz, nueva para la flora de Chile. Gayana Bot 68:313-315

Baeza M, Schrader O, Ruiz E and Negritto M (2008) Alstroemeria presliana Herb. (Alstroemeriaceae) in Chile from a cytogenetic perspective. Chil J Agr Res 68:328-333.

Baeza C, Ruiz E and Negritto M (2010) Comparative karyotypic analysis in the Alstroemeria hookeri Lodd. (Alstroemeria- ceae) complex sensu Bayer (1987). Genet Mol Biol 33:119124.

Baeza C, Rojas G and Ruiz E (2011a) El cariotipo fundamental de Alstroemeria patagonica Phil. (Alstroemeriaceae). Bol Soc Argent Bot 46:313-315.

Baeza C, Espejo J and Ruiz E (2011b) El cariotipo de Alstroemeria versicolor Ruiz et Pav. (Alstroemeriacerae). Gayana Bot 68:327-329.

Bayer E (1987) Die Gattung Alstroemeria in Chile. Mitt Bot Staatssamml München 24:1-362.

Buitendijk J and Ramanna M (1996) Giemsa C-banded karyotypes of eight species of Alstroemeria L. and some of their hybrids. Ann Bot 78:449-457.

Buitendijk J, Boon E and Ramanna M (1997) Nuclear DNA content in twelve species of Alstroemeria L. and some of their hybrids. Ann Bot 79:343-353.

Burkart A (1967) Sinopsis del género sudamericano de Leguminosas Adesmia DC. Darwiniana 14:463-568.

Cowling R, Rundel P, Lamont B, Arroyo M and Arianoutsou M (1996) Plant diversity in Mediterranean climates regions. Trends Ecol Evol 11:362-366.

Di Castri F (1981) Mediterranean-type schrubland of the world. In: Di Castri F, Goodall D, and Specht R (eds) Mediterranean-Type Schrubland. Elsevier, Amsterdam, pp 1-52.

Dimitrova D and Greilhuber J (2000) Karyotype and DNAcontent evolution in ten species of Crepis (Asteraceae) distributed in Bulgaria. Bot J Linn Soc 132:281-297.

Ehrhart C (2000). Die Gattung Calceolaria (Scrophulariaceae) in Chile. Bibliot Bot 153:1-283.

Jeu M, Sasbrink H, Garriga Calderé F and Piket J (1992) Sexual reproduction biology of Alstroemeria. Acta Hort 325:571575.

Kuipers A, Van Os De Jong H and Ramanna M (1997) Molecular cytogenetics of Alstroemeria: Identification of parental genomes in interspecific hybrids and characterization of repetitive DNA families in constitutive heterochromatin. Chromosome Res 5:31-39.

Lazo I, Ginocchio R, Cofré H, Vilina Y and Iriarte A (2008) Nuestra diversidad biológica. In: Rovira J, Ugalde J and Stutzin M (eds) Biodiversidad de Chile, Patrimonio y Desafíos. Ocho Libros Editores, Santiago de Chile, pp 49-55.

Levan A, Fredga K and Sandberg A (1964) Nomenclature for centromeric position on chromosomes. Hereditas 52:201220.

Marticorena C (1990) Contribution to the statistics of the vascular flora of Chile. Gayana Bot 47:85-113.

Matsumoto S, Marín-Morales M ,Ruas C and Ruas P (2000) Cytogenetic analysis of seven species of Eucalyptus L'Hér. (Myrtaceae). Caryologia 53:205-212.

Miyake I, Mobara S and Chiba K (1989) Breeding spotless Alstroemeria in Japan. Herbertia 45:40-44.

Mittermeier R, Gil P, Hoffmann M, Pilgrim J, Broks T, Mittermeier C, Lamoreux J and Fonseca G (2004) Hotspots Revised: Earth's Biologically Wealthiest and Most Threatened Ecosystems. Cemex, Mexico City, 390 pp.

Moreira A (2011) Plant geography of Chile. Springer, Heidelberg, $343 \mathrm{pp}$.

Muñoz M (2000) Novedades en la familia Alstroemeriaceae. Gayana Bot 57:55-59.

Muñoz M (2003) Tres nuevas monocotiledóneas descubiertas en Chile: Alstroemeria mollensis M. Muñoz et A. Brinck 
(Alstroemeriaceae), Miersia chilensis var. bicolor $\mathrm{M}$. Muñoz (Gilliesiaceae) y Calydorea chilensis M. Muñoz (Iridaceae). Gayana Bot 60:101-106.

Muñoz M and Moreira A (2003) Alstroemerias de Chile. Diversidad, Distribución y Conservación. Taller La Era, Santiago, $140 \mathrm{pp}$.

Myers N, Mittermeier R, Mittermeier C, Fonseca G and Kent J (2000) Biodiversity hotspots for conservation priorities. Nature 403:853-858.

Peruzzi L and Eroglu H (2013) Karyotype asymmetry: Again, how to measure and what to measure? Comp Cytogenet 7:1-9.

Reeves A (2001) MicroMeasure: A new computer program for the collection and analysis of cytogenetic data. Genome 44:239-443.

Schrader O, Budahn H and Ahne R (2000) Detection of 5S and 25S rRNA genes in Sinapis alba, Raphanus sativus and Brassica napus by double fluorescence in situ hybridization. Theor Appl Genet 100:665-669.
Schrader O, Ahne R and Fuchs J (2003) Karyotype analysis of Daucus carota L. using Giemsa C-Banding and FISH of $5 \mathrm{~S}$ and 18/25S rRNA specific genes. Caryologia 56:149-154.

Sleumer H (1968) Die Gattung Escallonia (Saxifragaceae). Tweede Reeks 58:1-146.

Stephens J, Tsuchiya T and Hughes H (1993) Chromosome studies in Alstroemeria pelegrina L. Int J Plant Sci 154:565-571.

Vergara O, Jerez V and Parra E (2006) Diversidad y patrones de distribución de coleópteros en la Región del Bíobío, Chile: Una aproximación preliminar para la conservación de la diversidad. Rev Chil Hist Nat 79:369-388.

Villagrán C and Hinojoza L (1997) Historia de los bosques de Sudamérica, II. Análisis fitogeográfico. Rev Chil Hist Nat 70:241-267.

Associate Editor: Marcelo Guerra

License information: This is an open-access article distributed under the terms of the Creative Commons Attribution License, which permits unrestricted use, distribution, and reproduction in any medium, provided the original work is properly cited. 